Ethiopian Journal of Environmental Studies \& Management 8(Suppl. 1): 738 - 751, 2015.

ISSN:1998-0507

doi: http://dx.doi.org/10.4314/ejesm.v8i1.1S

Submitted: April 09, 2014

Accepted: September 14, 2015

\title{
PHYSICOCHEMICAL CHARACTERIZATION OF CELLULASE PRODUCED FROM Kurthia gibsonii (CAC1) ISOLATED FROM CASSAVA DUMPSITES IN IBADAN, NIGERIA
}

\author{
*ADU, K.T., ${ }^{1}$ KAYODE, R.M.O. ${ }^{2}$ AND ADU, M.D. ${ }^{3}$ \\ ${ }^{1}$ Microbial Physiology and Biochemistry Research Unit, Department of Microbiology, \\ University of Ibadan, Ibadan, Nigeria \\ ${ }^{2}$ Division of Food Microbial Biotechnology and Toxicology, Department of Home Economics \\ and Food Science, University of Ilorin, P.M.B 1515, Ilorin, Nigeria \\ ${ }^{3}$ Department of Epidemiology and Medical Statistics, Faculty of Public Health, University of \\ Ibadan, Ibadan, Nigeria
}

\begin{abstract}
This experiment reports the physicochemical characterization of cellulase produced by Kurthia gibsonii CAC1 isolated from cassava dumpsites in Ibadan, Nigeria. Lineweaver-Burk plot of cellulase activities of K.gibsonii CAC1 was examined with $K_{\max }$ and $V_{\max }$ of the enzyme assayed. At optimal $\mathrm{pH}$ of 5.0, 10\% increase in enzymatic activities was observed. The enzymatic activities of $\mathrm{K}$. gibsonii CAC1 were optimal at $30^{\circ} \mathrm{C}$ and were still stable at $60^{\circ} \mathrm{C}$ with $50 \%$ reduction in cellulase activities. Cellulase activities of K. Gibsonii CAC1 showed significant difference $(p \geq 0.05)$ with the different cations used. There was no significant difference ( $p \leq 0.05$ ) observed with increased concentrations ( $p \leq 0.05)$ using two-way ANOVA. $\mathrm{Ca}^{2+}$ highly enhanced the cellulase activities of K.gibsonii CAC1 by $60 \%$ at 10mM. Highest inhibition by $\mathrm{Hg}^{2+}$ was observed at $20 \mathrm{mM}$ with $50 \%$ inhibition. At increasing concentration of the inhibitors, there was no significant difference $(p \leq 0.05)$ in cellulase activities; although the effect of each inhibitor on the enzymatic activity was significantly different ( $p \geq 0.05)$. Benzoic acid gave the highest inhibition of the cellulase activities in K. gibsonii CAC1 by 30\% at $20 \mathrm{mM}$, while Ethylene diamine-tetraacetic acid (EDTA) boosted the enzymatic activities by $10 \%$ at $10 \mathrm{mM}$. There was a significant difference $(p \geq 0.05)$ in the effect of different surfactants on the enzymatic activity but no significant difference $(p \leq 0.05)$ with the concentration of the surfactants on cellulase activity. Enzymatic activities of the bacterium were enhanced by Polyoxyethylenesorbitan mono-oleate (Tween 80) with a boost of 50\%. Increasing the concentration of sodium dodecyl sulphate (SDS) and Polyethylene glycol pisooctylphenylether (Trition $X-100$ ) caused a 70\% increase in cellulase activities. Cellulase of K. gibsonii CAC1 had $K_{\max }$ of $7.4 \times 10^{-2} \mathrm{mg} / \mathrm{ml}$ and $V_{\max }$ of $6.7 \times 10^{-1} \mu \mathrm{g} / \mathrm{sec}$. The cellulase described in this work have many properties that are similar to those obtained from other microbial sources and may be useful for various industrial applications.
\end{abstract}

Key Words: Kurthia gibsonii, Cellulase activity, Substrate concentration, Cations, Inhibitors, Surfactants

*Corresponding author: Adu, K.T.

Email: aduktus@gmail.com 


\section{Introduction}

Cellulase has attracted many scientific and industrial attention for its applications in many fields such as animal feed, textile, pulp and paper industries, ethanol production, laundry (Voragen, 1992; Godfrey and West, 1996; Tolan and Foody, 1999); de-inking of recycled paper (Smook, 1992; Moekerbak and Zimmermann, 1998). The importance of cellulase and allied enzymes is increasing in the global market. In the year 2000, the estimated world sale of industrial enzymes was put at 1.6 billion US dollars with cellulase occupying significant part (Demain, 2000). Microorganisms especially bacteria and fungi have played major roles in the production of enzymes such as cellulase and hemicellulase mainly due to low cost of production and the process is less expensive and not laborious (Karmakar and Ray, 2010).

Cellulase consists of three major components which are the endoglucanase, exoglucanase and $\beta$-glucosidase. Endoglucanase acts on carboxy methyl cellulose (CMC) and breaks the cellulose chains with resultant formation of glucose and cello-oligosaccharides; exoglucanase acts on microcrystalline cellulose (avicel), converting it to cellobiose as the primary product and beta-glucosidase causes the hydrolysis of cellobiose to glucose (Karmakar and Ray, 2011). The end product from this enzyme is glucose (Wood and McCrae, 1979).

Kurthia gibsonii CAC1 is a motile, aerobic, rod-shaped, non-pigmented and Gram positive bacterium which grow best at incubation temperature of $30^{\circ} \mathrm{C}$ and $\mathrm{pH}$ 5.5 with lactose and ammonium chloride supplemented medium as best carbon and nitrogen sources respectively (Adu et al., 2014). It has been investigated that Kurthia gibsonii CAC1 isolated from cassava dumpsites are capable of producing cellulase necessary to degrade cellulolytic components of cassava (Adu et al., 2014). Hence, researching into factors that may influence enzymatic activity of the cellulase produced by Kurthia gibsonii $\mathrm{CAC1}$ is the focus of this work.

\section{Materials and Methods \\ Sample Collection}

The bacterial isolate (Kurthia gibsonii CAC1) used for this study was collected from the culture collection centre of the Department of Microbiology, University of Ibadan and transported aseptically to the postgraduate laboratory of the department of Microbiology for further microbial analysis.

\section{Cellulase Enzyme Production}

This was done according to the modified method of Todar (2008). The composition of the optimized cellulase production medium was as follow: Lactose $(10 \mathrm{~g} / \mathrm{L}), \mathrm{K}_{2} \mathrm{HPO}_{4}(2 \mathrm{~g} / \mathrm{L}), \mathrm{KH}_{2} \mathrm{PO}_{4}(2.5 \mathrm{~g} / \mathrm{L})$, urea $(1.0 \mathrm{~g} / \mathrm{L}), \quad \mathrm{MgSO}_{4} .7 \mathrm{H}_{2} \mathrm{O} \quad(0.2 \mathrm{~g})$, $\mathrm{FeSO}_{4} .7 \mathrm{H}_{2} \mathrm{O}(0.01 \mathrm{~g} / \mathrm{L})$ and $\mathrm{MnSO}_{4} .7 \mathrm{H}_{2} \mathrm{O}$ $(0.007 \mathrm{~g} / \mathrm{L})$. Production medium was prepared by dissolving the above chemical constituents into conical flasks and then autoclaved at $121^{\circ} \mathrm{C}$ for $15 \mathrm{~min}$. The medium was later inoculated with $2 \mathrm{ml}$ of a $24 \mathrm{hr}$ old bacterial culture. A control experiment without bacterial inoculum was set up. They flasks were incubated for 24 to $72 \mathrm{hr}$ before harvesting the crude enzyme. The supernatant containing the crude enzyme was harvested by cold centrifuging at 5000rpm for $20 \mathrm{~min}$ using a Himac CR21GII high speed refrigerated centrifuge. The harvested supernatant was stored at $4^{\circ} \mathrm{C}$ for further analysis.

\section{Characterization of the Cellulase Enzymes}

The activities of the cellulase enzyme from the bacteria were characterized considering the effects of temperature, $\mathrm{pH}$, substrates, metal ions, inhibitors, and surfactants. 
Assessment of the Optimum pH for Crude Cellulase Production

One millitre each of $0.1 \mathrm{M}$ citratephosphate buffer adjusted to various $\mathrm{pH}$ values (4.0-9.0) was inoculated with $1 \mathrm{ml}$ of the enzyme and incubated at $30^{\circ} \mathrm{C}$ for $1 \mathrm{hr}$. Volume of $30 \mu \mathrm{L}$ of each cellulase enzyme was inoculated aseptically into a $5 \mathrm{~mm}$ well on CMC agar medium. The agar plate was then incubated at $30^{\circ} \mathrm{C}$ for $24 \mathrm{hr}$. This was done according to the modified method of Bertrand et al. (2004). After the incubation period; Gram's iodine solution was used to flood the plates and allowed to stand for $30 \mathrm{~min}$. The diameter of the hydrolytic zone formed around the site of inoculation was measured and taken to represent the activity of the enzyme.

Determination of the Optimum Temperature for Crude Cellulase Production

One millilitre of the crude enzyme extract was introduced into four (4) test tubes. One test tube each was incubated at $25,30,37$, and $45^{\circ} \mathrm{C}$ respectively for $15 \mathrm{~min}$. At the end of incubation, the crude enzyme extract was aseptically introduced into a $5 \mathrm{~mm}$ well on CMC agar medium. The agar plates were then incubated at $30^{\circ} \mathrm{C}$ for $24 \mathrm{hr}$ according to the modified method of Bertrand et al. (2004). After the incubation period, Gram's iodine solution was used to flood the plates and was allowed to stand for $30 \mathrm{~min}$. The diameter of the hydrolytic zone formed around inoculation site, after the addition of iodine, was measured and taken to represent the activity of the enzyme. Each treatment was carried in three replicates.

Assessment of Temperature Stability of the Crude Enzyme

This was done according to the modified method of Bertrand et al. (2004). The enzyme sample was divided into four groups in glass test tubes and incubated at various temperatures of $25,30,37$, and $45^{\circ} \mathrm{C}$ respectively before incubation for $24 \mathrm{hr}$. Volume of $30 \mu \mathrm{L}$ of each crude cellulase enzyme in the test tube was aseptically inoculated into a $5 \mathrm{~mm}$ well on CMC agar plates. The agar plates were then incubated at $30^{\circ} \mathrm{C}$ for $24 \mathrm{hr}$. Gram's iodine solution was used to flood the plates and allowed to stand for $30 \mathrm{~min}$. The diameter of the hydrolytic zone formed around inoculation site was measured and taken to represent the residual activity of the enzymes.

Investigation on the Effects of Cations, Inhibitors and Surfactants on Cellulase Activity

One milliitre of enzyme samples was introduced into varying concentration of the cations (5, 10, 15 and $20 \mathrm{mM})$, inhibitors and surfactants $(0.25,0.5,0.75$, 1.0 and $1.25 \%$ ) and incubated at $30^{\circ} \mathrm{C}$ for $1 \mathrm{hr}$. Then $30 \mu \mathrm{L}$ of each cellulase enzyme was aseptically inoculated into a $5 \mathrm{~mm}$ well on CMC agar medium. Control sample was inoculated with equal quantity of enzyme and buffer mixture. The agar plates were incubated at $30^{\circ} \mathrm{C}$ for $24 \mathrm{hr}$ according to the modified method of Bertrand et al. (2004). Gram's iodine solution was used to flood the plates and allowed to stand for $30 \mathrm{~min}$. The diameter of the hydrolytic zone formed around inoculation site was measured and taken to represent the residual activity of the enzymes. Chemical used include: $\mathrm{NaCl}$, $\mathrm{CaCl}_{2}, \mathrm{HgCl}_{2}, \mathrm{MgCl}_{2}, \mathrm{NH}_{4} \mathrm{Cl}$, Urea, Benzoic acid, EDTA (Ethylenediaminetetraacetic acid), SDS (sodium dodecyl sulphate), Triton X-100 (Polyethylene glycol pisooctylphenylether), and Tween 80 (Polyoxyethylenesorbitan mono-oleate).

Assessment on the Effect of Substrate Concentrations on Crude Cellulase Activity

This was done according to the modified method of Bertrand et al. (2004). Increasing concentrations $(0.5,1,1.5,2.0$ and $2.5 \% \mathrm{w} / \mathrm{v}$ ) of carboxy-methyl cellulose was dissolved in $0.1 \mathrm{M}$ citrate phosphate buffer at $\mathrm{pH} 6.0$ and used for enzyme assay 
without increasing the enzyme volume. One millilitre of each solution was added to one millilitre enzyme sample and incubated at $50^{\circ} \mathrm{C}$ for $30 \mathrm{~min}$. Quantities of reducing sugar released was measured according to Miller (1959). A reciprocal of quantity of reducing sugar recorded was plotted against a reciprocal of the substrate concentration. The $\mathrm{V}_{\max }, \mathrm{K}_{\max }$ and the regression equation were determined from the line equation obtained.

\section{Statistical Analysis}

The analysis of variance (ANOVA) was carried out with $95 \%$ confidence level on the effect of physicochemical properties on the growth and cellulase activities of isolates CAC1 and CAC2.

\section{Results}

\section{Effect of pH on cellulase activities}

Figure 1 shows the effect of increasing $\mathrm{pH}$ on cellulase activity by K.gibsonii CAC1. As $\mathrm{pH}$ was increased from 5.0 to 8.0 , there was a gradual decrease in the cellulase activity produced by K.gibsonii CAC1 from optimal $\mathrm{pH}$ of 5.0 until minimum $\mathrm{pH}$ was observed at 8.0. Increase in $\mathrm{pH}$ from 5.0 to 8.0 did not result in an increase in cellulase activity, rather a $40 \%$ reduction in activity was observed.

\section{Effect of Temperature on Cellulase Activities}

The effect of varying incubation temperature on cellulase activity by K.gibsonii CAC1 is illustrated in Figure 2. At $25^{\circ} \mathrm{C}$, there was an increase in cellulase activity (100\%). Highest activity (400\%) was recorded at $30^{\circ} \mathrm{C}$ and this represented $300 \%$ increase in the cellulase activity of K.gibsonii CAC1enzyme. Further increase in temperature to $37^{\circ} \mathrm{C}$ led to $250 \%$ increase in enzyme activity.

\section{Effect of Temperature Stability on Cellulase Activities}

Figure 3 illustrates the response of $K$. gibsonii CAC1 cellulase to incubation temperature relative to time. It was observed that the enzyme was stable at high temperature of $60^{\circ} \mathrm{C}$. When incubated for $30 \mathrm{~min}$ at $30^{\circ} \mathrm{C}$, there was a sharp increase in residual activity $(100 \%)$ and further incubation resulted in the reduction of the activity. Incubation at $37^{\circ} \mathrm{C}$ initially resulted in increase in the residual activity $(50 \%)$ but a slight reduction in activity (20\%) was noted after 30 min of incubation before a gradual rise in activity was recorded.

\section{Effect of Cations on Cellulase Activities}

Figure 4 shows the effect of cations on cellulase activity of K.gibsonii CAC1. Addition of $\mathrm{Ca}^{2+}$ at increasing concentration $(5,10,15$ and $20 \mathrm{mM})$ highly enhanced the cellulase activity with optimal enhancement at $10 \mathrm{mM}$ giving $60 \%$ increase in cellulase activity after which there was a decline in the boost. $\mathrm{NH}_{4}{ }^{+}$also enhanced enzymatic activity of the cellulase, at lesser degree compared to $\mathrm{Ca}^{2+}$. At $5 \mathrm{Mm} \mathrm{NH}_{4}{ }^{+}$, enzymatic activity was increased by $30 \%$ but only $10 \%$ increase was observed when concentration was increased to $10 \mathrm{Mm}$. An increase of $20 \%$ was recorded as the concentration was further increased to $15 \mathrm{Mm}$. At reduced concentration of $5 \mathrm{mM}$, the enzymatic activities were boosted (10\%) by the addition of $\mathrm{Mg}^{2+}$ after which further increase in concentration of the cations did inhibit the cellulase activities. The higher the concentration added, the higher the inhibition recorded. The highest inhibition (50\%) was recorded with $\mathrm{Hg}^{2+}$ at $20 \mathrm{mM}$. The peak enhancement concentration of $\mathrm{Na}^{+}(10 \%)$ was observed at $15 \mathrm{mM}$ after which there was a decline, with lower concentrations giving a mild inhibition of cellulase activity.

\section{Effect of Enhancers or Inhibitors on Cellulase Activities}

Figure 5 shows the effect of enhancers/inhibitors on cellulase activity of K.gibsoniiCAC1 at increasing concentration $(5,10,15$ and $20 \mathrm{mM})$. Urea did not show any observable effect on the cellulase activities as the concentration 
increased. Inhibition was recorded with benzoic acid as the concentration increased with highest inhibition (30\%) observed at $20 \mathrm{mM}$. Increase in the concentration of EDTA resulted in enhanced activities $(10 \%)$ of the enzyme at $10 \mathrm{mM}$.

\section{Effect of Surfactants on Cellulase Activities}

Figure 6 shows the effect of surfactants concentrations on cellulase activities of K.gibsonii CAC1. Increase in concentration of Tween 80 initially increased enzyme activities of $K$. gibsonii CACluntil highest activity increase $(40 \%)$ was observed at $0.5 \%$ after which further increase in concentration of Tween 80 caused a gradual decrease in cellulase activity. Increase in concentration of Triton $\mathrm{X}-100$ resulted in gradual increase in cellulase activity of $K$.gibsonii CAC1 with peak increase $(80 \%)$ recorded at $1.25 \%$. There was an initial increase in cellulase activity $(20 \%)$ of $K$. gibsonii CAC1 at $0.25 \%$ SDS after which further increase in concentration resulted in gradual decrease in enzymatic activity (10\%) until least activity was recorded at $1.25 \%$.

$K_{\text {max }}$ and $V_{\text {max }}$ Determination and Effect of Increasing Substrate Concentration

Effect of different concentrations of carboxymethyl cellulose on cellulase activity of K.gibsonii CAC1 was studied and the Michaelis-Menten kinetic constants $K_{\max }$ and $V_{\max }$ for the cellulase were determined. Cellulase of K.gibsonii CAC 1 showed maximum activity at $0.8 \%$ carboxymethyl cellulose concentration with a linear increase up to this concentration. Above this concentration, a decrease in the enzyme activity was observed. Line weaver-Burk plot for the enzyme activity is shown in Figure 7. Cellulase of K.gibsonii CAC1 had a Michaelis constant $\left(\mathrm{K}_{\max }\right)$ of $7.4 \times 10^{-2}$ $\mathrm{mg} / \mathrm{ml}$ and a peak enzyme activity $\left(\mathrm{V}_{\max }\right)$ of $6.7 \times 10^{-1} \mu \mathrm{g} / \mathrm{sec}$.

\section{Discussion}

At increasing $\mathrm{pH}$ values, cellulase activities of Kurthia gibsonii CAC1 were not significantly different $(\mathrm{p} \leq 0.05)$ considering their two-way analysis of variance. Cellulase activity of $K$. gibsonii $\mathrm{CAC1}$ however was optimum at $\mathrm{pH} 5.0$ while, further increase in $\mathrm{pH}$ did not favour the enzymatic activities. This is similar to earlier report by Immanuel et al. (2006), who reported that Micrococcus sp, Bacillus $\mathrm{sp}$, and Cellulomas sp had maximum activities at pH 7.0. Odeniyi et al. (2009) reported the cellulase activity of a Bacillus coagulans strain isolated from a fermenting palm-fruit residue to be $\mathrm{pH}$ tolerant at 4.0 to 9.0 . A similar report by Gautam et al. (2010) on a cellulase enzyme from Pseudomonas sp showed a broad range activity at $\mathrm{pH}$ optimum of 7.5.

There gradual increase in cellulase activities of K.gibsonii $\mathrm{CAC} 1$ at $25^{\circ} \mathrm{C}$ with optimal temperature observed at $30^{\circ} \mathrm{C}$ which lead to sharp decrease in enzyme activities is similar to the report given by Itoandon et al. (2011) which showed that Aspergillus niger had optimum temperature for cellulase activities at $30^{\circ} \mathrm{C}$. Report by Otajevwo and Aluyi, (2010), showed that Psuedomonas aeruginosa had peak cellulase activities at $40^{\circ} \mathrm{C}$ and similarly, optimal temperature of $40^{\circ} \mathrm{C}$ was reported for Aspergillus niger Z10 strain by Gokhancoral et al. (2002). Cellulase activities from Trichoderma sp and other mesophilic cellulolytic fungi are at their optimum when assayed at about $50^{\circ} \mathrm{C}$ (Mandels et al., 1974; Tangnu et al., 1981 and Kawamori et al., 1987). The least growth of $K$. gibsonii CAC1 was observed at $\mathrm{pH}$ 3.5. The cellulase activities of $K$. gibsonii $\mathrm{CAC1}$ at various temperatures used were not significantly different $(p \leq 0.05)$ when incubated at different incubation period.

Cellulase activities of $K$.gibsonii CAC1 showed a significant difference $(\mathrm{p} \geq 0.05)$ with different cations used but no 
significant difference $(\mathrm{p} \leq 0.05)$ was observed with increasing concentration using two-way ANOVA. Of all the cations studied, it was discovered that the addition of $\mathrm{Ca}^{2+}$ resulted in highest cellulase activities of K.gibsonii CAC1 with optimal activity recorded at $10 \mathrm{mM}$. Addition of $\mathrm{Ca}^{2+}$ at increasing concentration $(5,10,15$ and $20 \mathrm{mM}$ ) highly enhanced the cellulase activities with optimal boost giving $60 \%$ increase. At reduced concentration of $5 \mathrm{mM}$, the enzymatic activities were boosted $(10 \%)$ by the addition of $\mathrm{Hg}^{2+}$ and $\mathrm{Mg}^{2+}$. Increasing concentration of $\mathrm{Hg}^{2+}$ and $\mathrm{Mg}^{2+}$ resulted in inhibition of the activities of the cellulase but enhanced activities at low concentrations. The higher the concentration of $\mathrm{Hg}^{2+}$ and $\mathrm{Mg}^{2+}$ added; the higher the inhibition recorded. The highest inhibition $(50 \%)$ was recorded with $\mathrm{Hg}^{2+}$ at $20 \mathrm{mM}$. This was in contrast to the findings of Odeniyi et al. (2009) who recorded total inhibition of cellulase activities in Bacillus coagulans after the addition of $1 \mathrm{mM}$ $\mathrm{HgCl}_{2}$ solution. Igbal et al. (2011) reported that $\mathrm{Hg}^{2+}$ had partial inhibition on purified cellulase activities from Trichoderma viride isolated from wheat straw.

At increasing concentration of the inhibitors, there was no significant difference $(\mathrm{p} \leq 0.05)$ in the cellulase activities of K.gibsonii CAC1 but the effect of each inhibitor on the enzymatic activity was significantly different $(p \geq 0.05)$. Urea showed similar effect shown by the control on the cellulase activities of K.gibsonii CAC1 as the concentration increased. Benzoic acid showed pronounced inhibitory effect on the enzyme. Inhibition was recorded with benzoic acid as the concentration increased with highest inhibition (30\%) observed at $20 \mathrm{mM}$. Increase in EDTA concentration resulted in enhanced cellulase activities with highest boost recorded at $10 \mathrm{mM}$ after which there was decrease in activities of the cellulase enzyme.
At lower concentrations of Tween 80 up till $0.5 \%$, cellulase activities of K.gibsonii CAC1 were enhanced, although this was followed by decrease in the enzymatic activities as the concentration was increased. Enzymatic activities of the bacteria were enhanced by Tween 80 with highest boost of $50 \%$ observed in $K$. gibsonii CAC1. There was $70 \%$ increase in cellulase activities when Trition X-100 was added. Igbal et al., 2011, reported that SDS, and EDTA showed inhibitory effect on purified cellulase activity from Trichoderma viride isolated from wheat straw.

Using carboxy methyl cellulose as substrate, the enzyme showed maximum activity $\left(\mathrm{V}_{\max }\right)$ of $0.67 \mu \mathrm{g} / \mathrm{sec}$ with its corresponding $\mathrm{K}_{\max }$ value of $0.074 \mathrm{mg} / \mathrm{ml}$ for K.gibsonii CAC1. In literature, different ranges of $\mathrm{K}_{\max }$ and $\mathrm{V}_{\max }$ for different microorganisms, especially fungal species have been reported. According to Ekperigin (2007), $\mathrm{K}_{\max }$ values for A. anitratus and Branhamella sp. were 0.32 and $2.54 \mathrm{mM}$ respectively for cellobiose as substrate, while for CMC substrate the values recorded were 4.97 and $7.90 \mathrm{mg} / \mathrm{mL}$ for the same species respectively. Similarly, $K_{\mathrm{m}}$ value of 3.6 $\mathrm{mg} / \mathrm{mL}$ for Pseudomonas fluorescens and $1.1 \mathrm{mg} / \mathrm{mL}$ for Trichoderma reesei were reported by Bakare et al. (2005) and Cascalheira and Queiroz, (1999) respectively were reported. Odeniyi et al. (2009) reported the $K_{\max }$ and $V_{\max }$ of a carboxy-methyl-cellulase from Bacillus coagulans strain to be $0.65 \mathrm{mg} / \mathrm{ml}$ and $1.36 \mu \mathrm{g} / \mathrm{sec}$ respectively.

\section{Conclusion}

Kurthia gibsonii CAC1 produced cellulase which is a thermostable enzyme whose activities are enhanced by some cations such as $\mathrm{Ca}^{2+}$ and $\mathrm{Mg}^{2+}$ and partially inhibited by $\mathrm{Hg}^{2+}$. They were able to grow at $\mathrm{pH}$ range of 5-7 and optimum temperature of $30^{\circ} \mathrm{C}$. The novel 
microorganism can be used for the production of cellulase with various industrial applications and to aid in degradation of cellulolytic wastes.

\section{Acknowledgements}

The authors would wish to appreciate support received from the postgraduate laboratory technologists, Department of Microbiology, University of Ibadan in course of the research work.

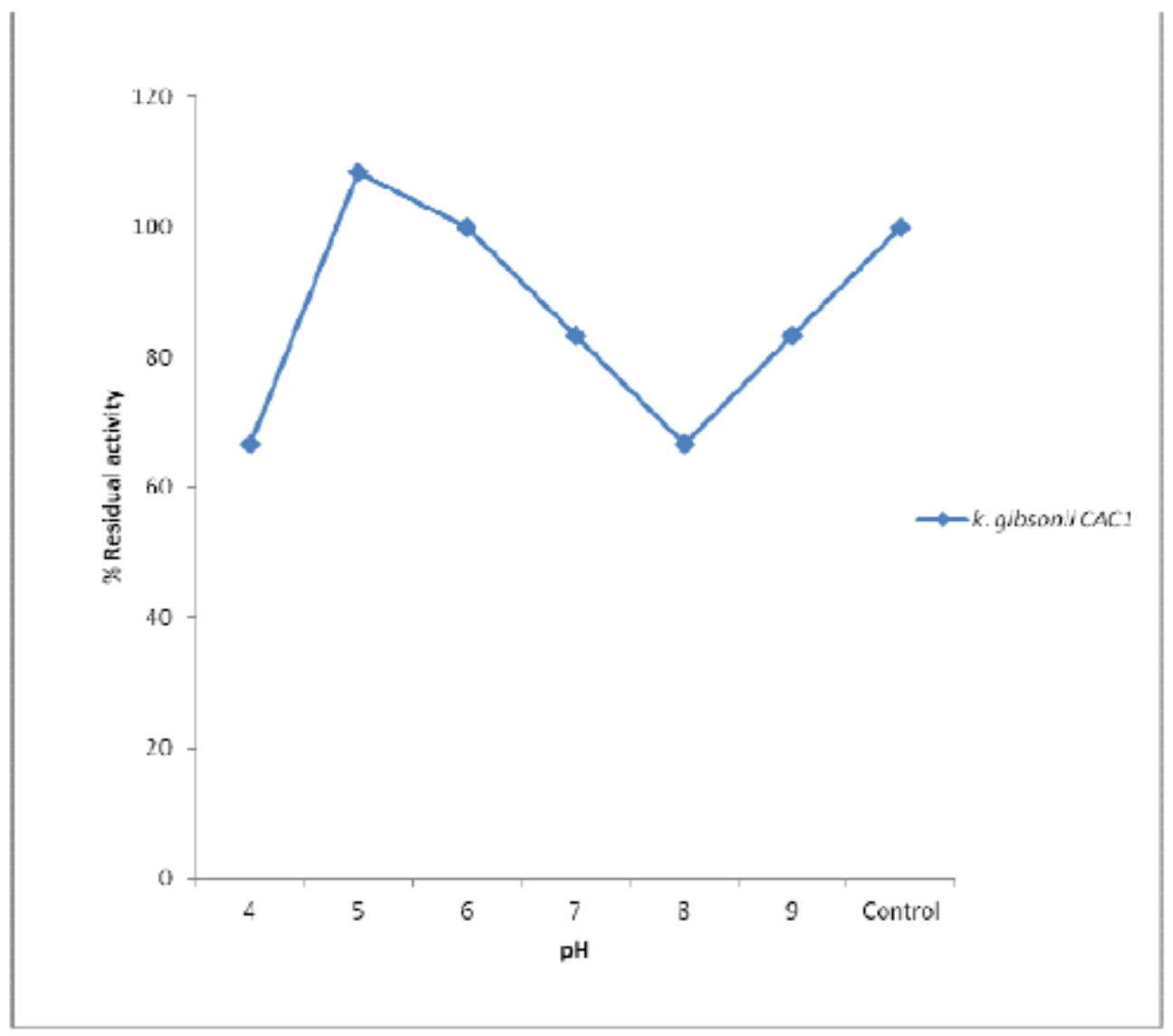

Figure 1: Effect of $\mathrm{pH}$ on the cellulase activities of $K$. gibsonii CAC1 


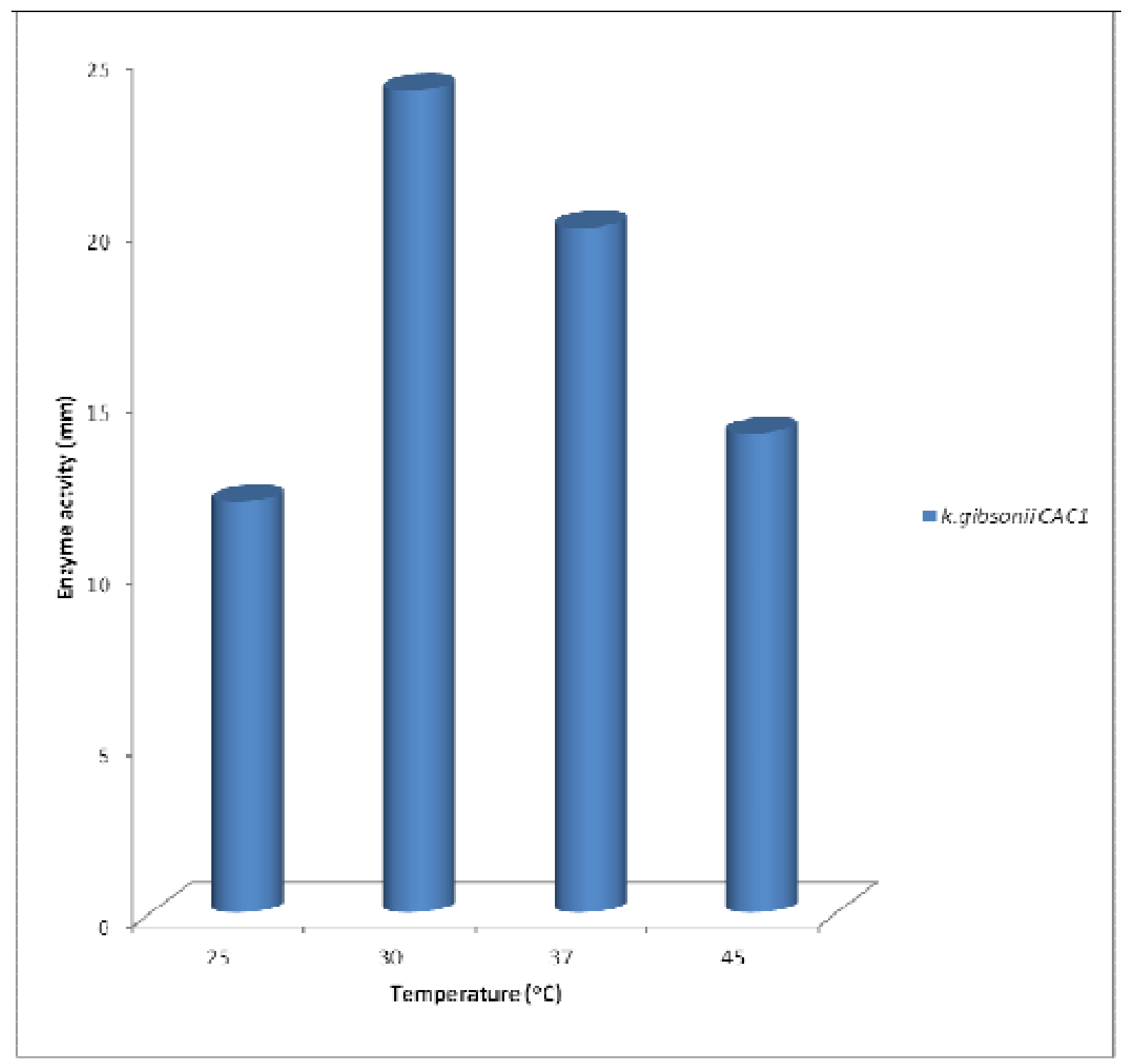

Figure 2: Effect of temperature on cellulase activities of $K$. gibsonii CAC1 
Ethiopian Journal of Environmental Studies and Management Vol. 8 (Suppl. 1) 2015

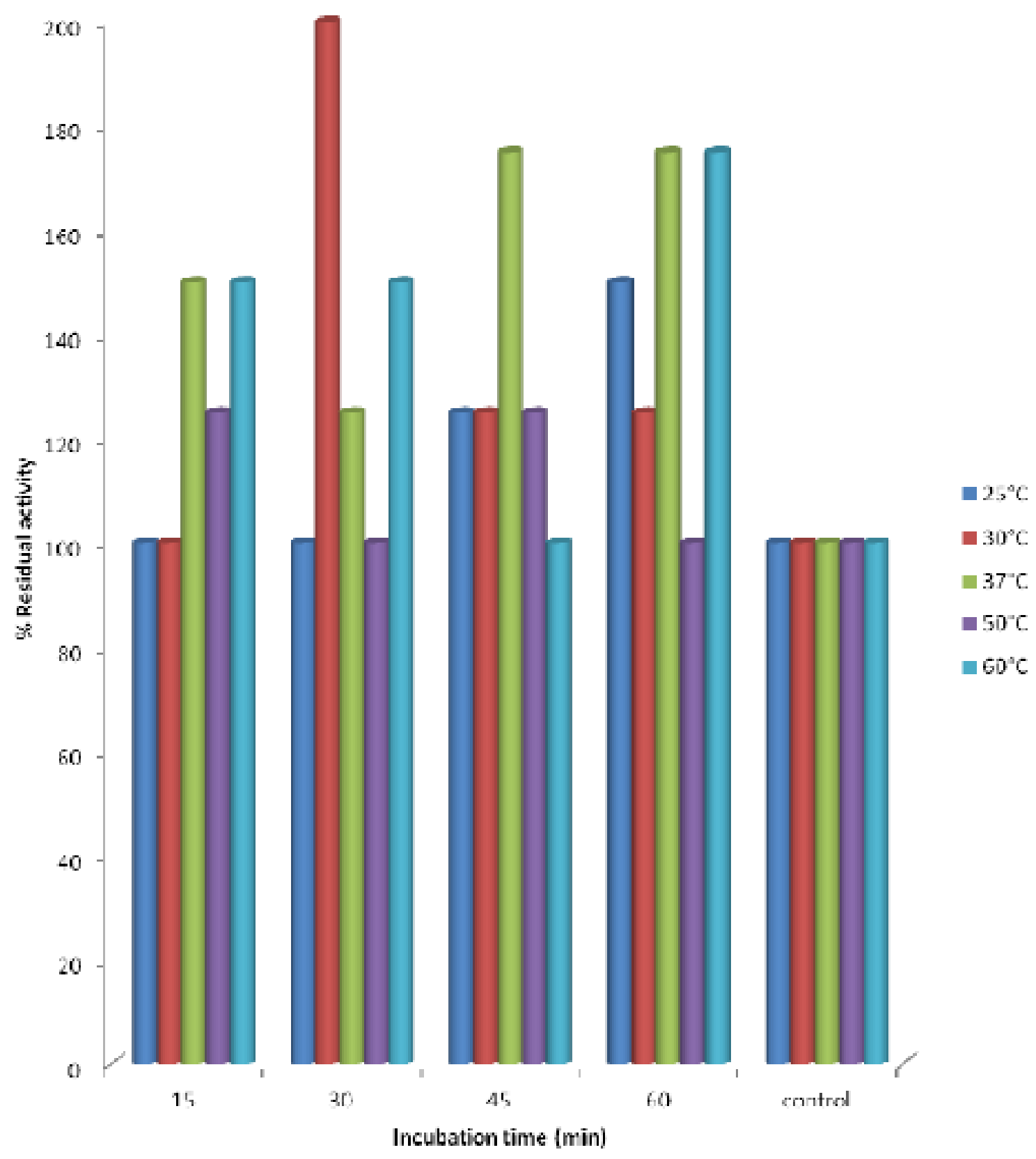

Figure 3: Response of $K$. gibsonii CAC1cellulase to incubation temperature relative to time 
Physicochemical Characterization of Cellulase Produced from Kurthia gibsonii.................ADU et al.

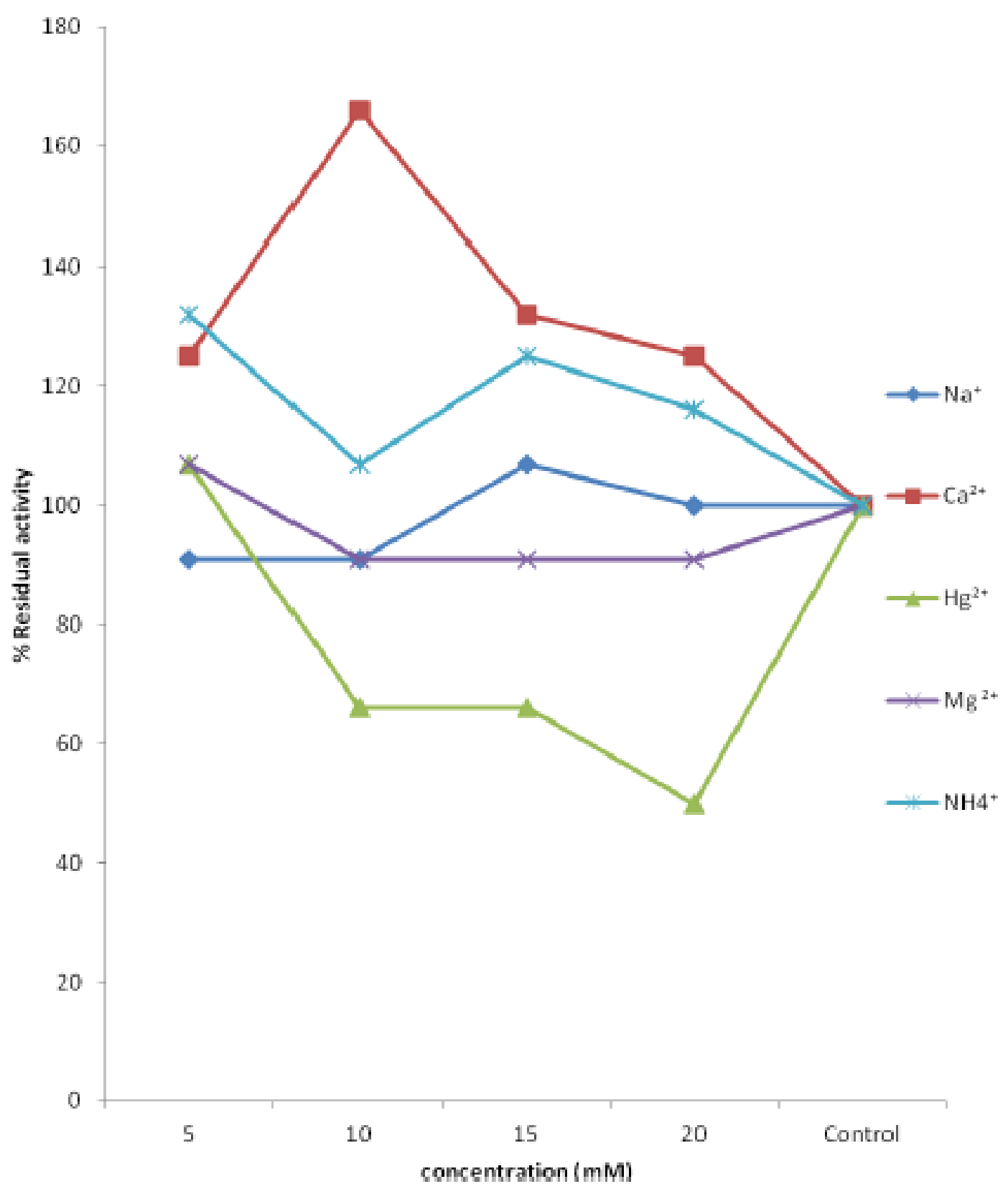

Figure 4: Effect of cations on cellulase activity of $K$. gibsonii CAC1 
Ethiopian Journal of Environmental Studies and Management Vol. 8 (Suppl. 1) 2015

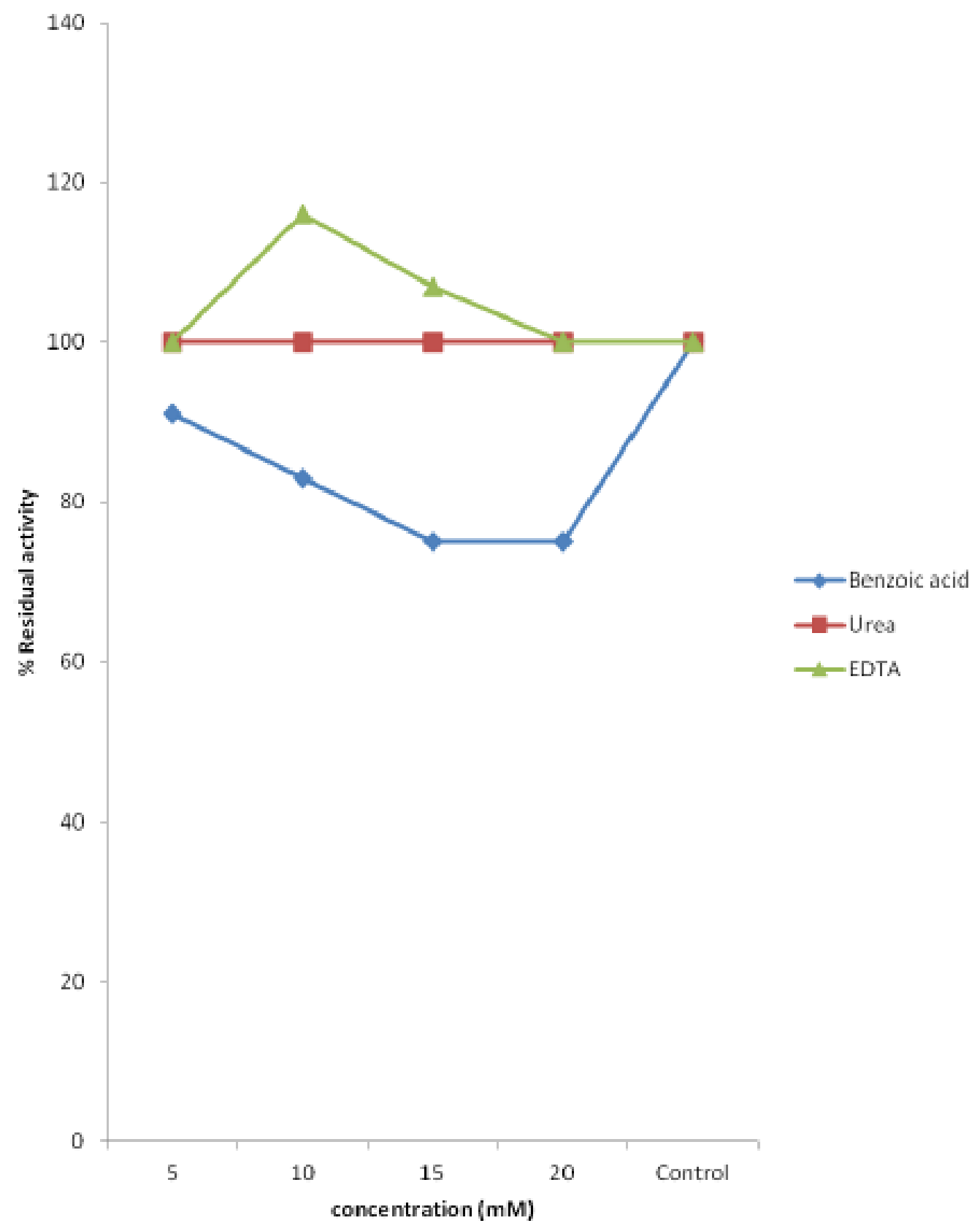

Figure 5: Effect of inhibitors/enhancers on cellulase activity of $K$. gibsonii CAC1 


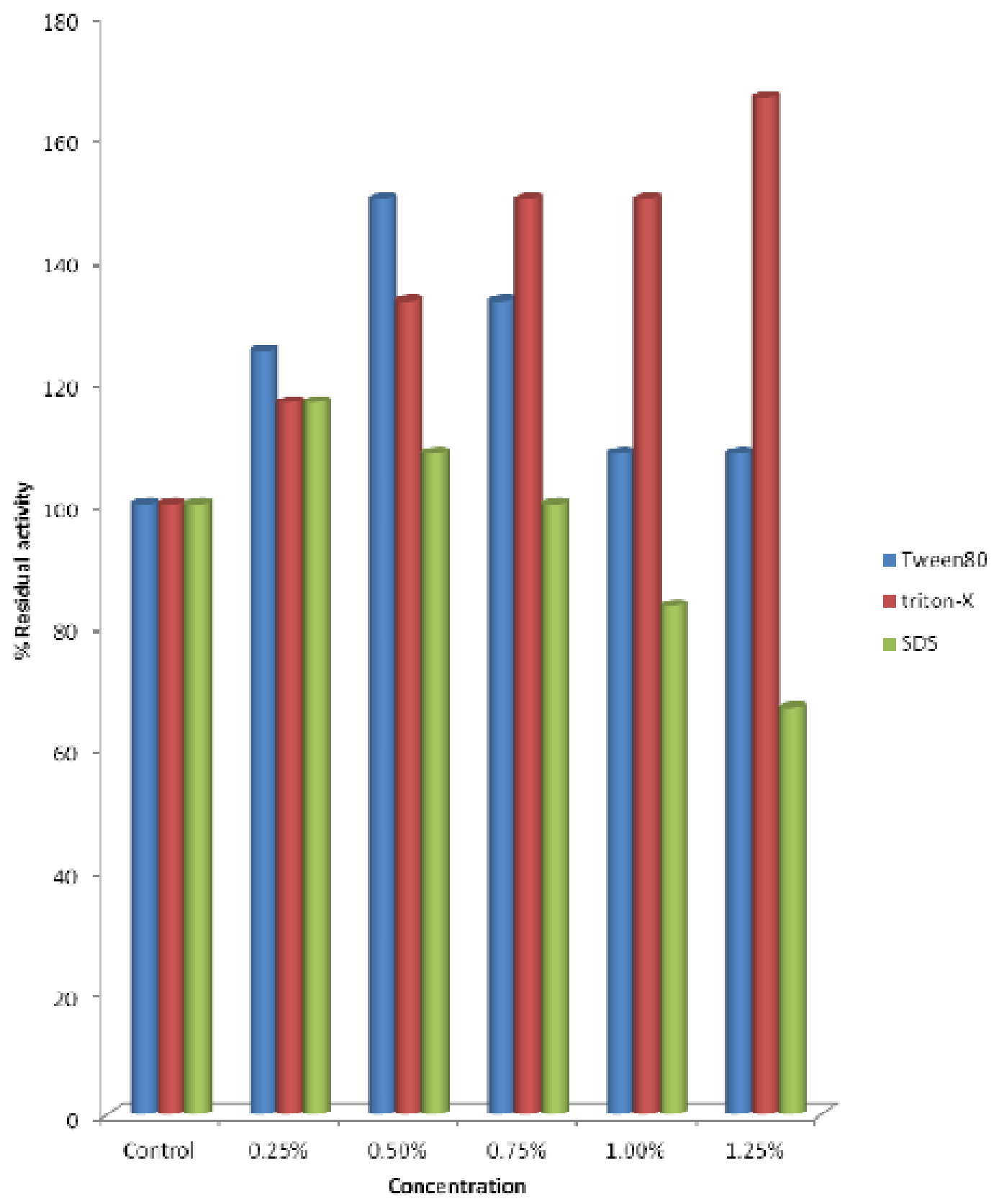

Figure 6: Effect of surfactants on cellulase activity of $K$. gibsonii CAC1 


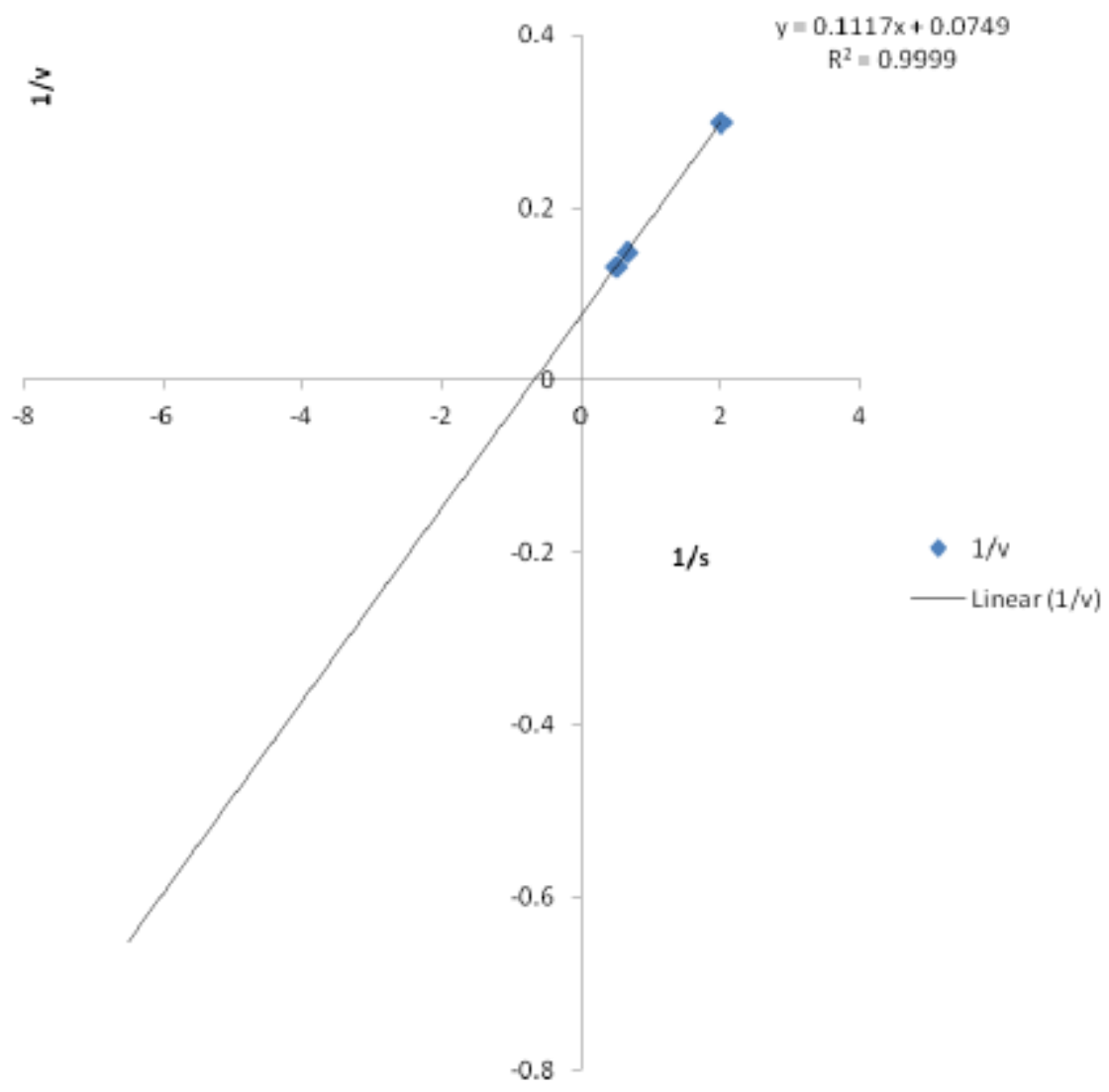

Figure 7: Lineweaver-Burk plot of CMCase activity of $K$. gibsonii CAC1

\section{References}

Adu, K.T., Kayode, R.M.O., Oni, M.O and Adu, M.D. (2014). Optimal culture Conditions and Characterization of Cellulolytic Bacteria from Cassava Dumpsites in Ibadan, Nigeria. Ethiopian Journal of Environmental Studies and Management, 7(3): Bakare, M.K. (2005). Purification and characterization of cellulase from the wild-type and two improved mutants of Pseudomonas fluorescens. African Journal of Biotechnology, 4: 898-904.

Bertrand, T.F., Frederic, T., and Robert, N. (2004). Production and Partial Characterization of thermostable amylase from Ascomycetes yeast strain isolated from starchy soil. McrGrawHill Inc, New York. pp. 5355.

Cascalheira, J.F. and Queiroz, J.A., (1999). Kinetic study of the cellobiase activity of Trichoderma reesei cellulose complex at high substrate concentrations. Letters, 21: 651-655.

Demain, A.L. (2000). Microbial biotechnology. Trends Biotechnology, 18: 26-31.

Ekperigin, M.M., (2007). Preliminary studies of cellulase production by Acinetobacter anitratus and Branhamella sp. African Journal of Biotechnology, 6: 28-33.

Gautam, S.P., Bundela, P.S., Pandey, Jamaluddin A.K, Awasthi, M.K and Sarsaiya,S. (2010). Cellulase production by Psuedomonas sp. Isolated from municipal solid waste compost. International Journal of Academic Reasearch, 2(6): Part II.

Godfrey, T. and West, S. (1996). Industrial Enzymology. 2nd Edition, Macmillan Publishers Inc., New York. 
Go khan-Coral, G., Burhan, A.N., Naldi, M. and Hatice, G. V. (2002). Some properties of crude carboxymethyl cellulase of Aspergillus niger Z10 Wild-Type strain. Turkish journal of Biology, 26: 209-213.

Immanuel, G., Dhanusa, R., Prema, $\mathrm{P}$ and Palavesa, A. (2006). Effects of different growth parameters on endoglucanase enzyme activity by bacteria isolated from coir retting effluents of estuarine environment. International Journal of Environmental Science and Technology. 3(1): 25-34.

Karmakar, M. and Ray R.R. (2011). Current Trends in Research and Application of Microbial Cellulases. Research Journal of Microbiology, 6: 41-53.

Karmakar, M. and Ray, R.R., (2010). Characterization of extracellular thermostable endoglucanase from Rhizopus oryzae using response surface methodology. Research Revision Bioscience, 4: 50-55.

Kawamori, M., Takaymma, K. and Takasawa, S. (1987). Production of cellulase by a thermophilic fungus Thermoascus aurantiacus, A-131. Agricultural, Biology and Chemistry, 51: 647-654.

Mandels, M., Hontz, L. And Nystron, J. (1974). Enzymatic hydrolysis of waste cellulose. Biotechnology and Bioengineering. 16: 147-1493.

Miller, G.L. (1959). Use of Dinitrosalisylic Acid Reagent for Determination of Reducing Sugar. Analytical Chemistry. 31:426-428.

Moekerbak, A.L. and Zimmermann, W, (1998). Applications of Enzymes in Paper Deinking Processes. In: Enzyme Applications in Fiber
Processing, Eriksson, K. and A. Cavaco-Paulo (Eds.). Vol. 687. American Chemical Society, Washington, D.C., ISBN-13: 9780841235472e, pp: 133-141.

Odeniyi, O.A., Onilude A.A. and Ayodele M.A. (2009). Production characteristics and properties of cellulase/ polygalacturonase by a Bacillus coagulans strain from a fermenting palm-fruit industrial residue. African Journal of Microbiology Research, 3(8): 407417.

Otajevwo, F.D and Aluyi, H.S.A. (2010). Cultural conditions necessary for optimal cellulase yield by cellulytic bacterial organisms as they relate to residual sugars released in broth medium. Nigerian Journal of Microbiology, 24(1): 2168-2182.

Smook, G. (1992). Secondary Fiber in Handbook for Pulp and Paper Technologists. Angus Wilde Publications, Vancouver, Canada, pp: 209-218.

Todar, G. (2008). Laboratory methods in food and diary microbiology. London. Academic Press.

Tolan, J.S. and Foody B. (1999). Cellulase from Submerged Fermentation. In: Advances in Biochemical Engineering/Biotechnology, Scheper, Th. (Ed.). Vol. 65. Springer, Berlin / Heidelberg, ISBN: 978-3-540-655770, pp: 41-67.

Voragen, A.G.J. (1992). Tailor-made enzymes in fruit juice processing. Fruit Processing, 7: 98-102.

Wood, T.M. and McCrae, S.I. (1979). Synergism between enzymes involved in the solubilization of native cellulose. Advanced Chemistry Series, 181: 181-209. 